16 a 18 de outubro de 2019 - Campinas | Brasil

\title{
Prevenindo intoxicações em crianças: construção de cartilha educativa.
}

\section{Priscila T. Miyagusuko*, Maira D. Misko.}

\section{Resumo}

As intoxicações são emergências clínicas pediátricas recorrentes, sendo elas causadas por animais peçonhentos,medicamentos ou domissanitários. Esta pesquisa teve como objetivo elaborar um instrumento educativo, na forma de cartilha, sobre a prevenção de intoxicações na infância.O projeto foi realizado através do desenvolvimento de um estudo do tipo metodológico que se refere à elaboração e validação de um instrumento educativo. A cartilha poderá ser utilizada como um recurso para a disseminação do conhecimento e da informação, buscando colaborar na redução dos acidentes na infância decorrente de intoxicações, bem como auxiliando na busca por auxílio à saúde na ocorrência de um destes acidentes.

\section{Palavras-chave:}

intoxicações, acidentes na infância, prevenção.

\section{Introdução}

As intoxicações são emergências clínicas pediátricas recorrentes. A partir de dados recentes do SINITOX, a idade entre 01 e 04 anos é a que mais possui casos registrados. ${ }^{1}$ Estudos científicos que visam a prevenção destes acidentes são escassos.

O objetivo foi elaborar um instrumento educativo, na forma de cartilha, sobre a prevenção de intoxicações na infância.

\section{Resultados e Discussão}

A elaboração da cartilha seguiu as fases: revisão da literatura, planejamento da estrutura e conteúdo, levantamento das demandas da população, construção da cartilha, validação do conteúdo. Foram entrevistados 12 professores de educação infantil e 14 familiares de crianças e as demandas levantadas para a construção da cartilha foram: prevenção e primeiros socorros com intoxicações envolvendo domissanitarios, medicamentos, plantas tóxicas e regras gerais para a segurança de ambientes domésticos e escolares, bem como telefones de emergência.

A utilização de manuais, folhetos e cartilhas é considerada uma estratégia positiva na promoção da saúde. ${ }^{2}$ Estratégias de prevenção de acidentes visam o aumento do acesso à informação, ampliação do conhecimento, esclarecimento de dúvidas e redução de danos. $^{3}$

A seguir serão apresentadas duas figuras para exemplificar a cartilha construída o projeto. A figura 1 é a capa do material educativo e a figura 2, uma das páginas que aborda o contato com escorpião.
Figura 1 - Capa da cartilha

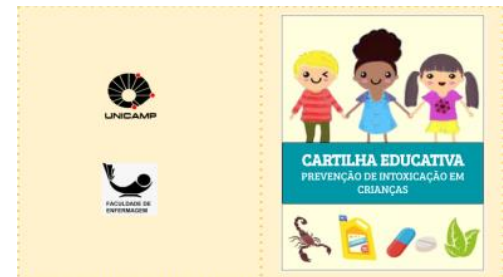

Figura 2 - Acidente escorpiônico e contato com cobras

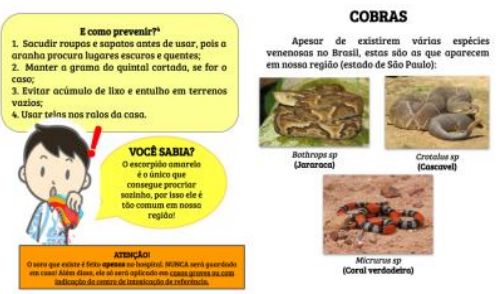

\section{Conclusões}

A cartilha será um recurso utilizado como disseminação de conhecimento e informação, a fim de auxiliar na ocorrência desta exposição, mas também na redução deste tipo de acidente.

\section{Agradecimentos}

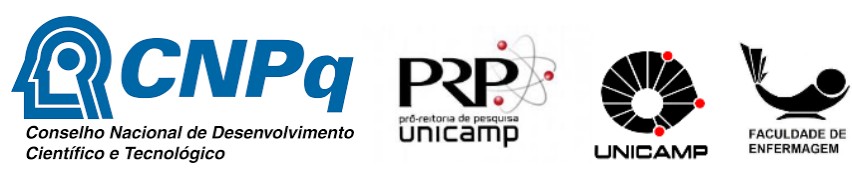

1. Fundação Oswaldo Cruz, Ministério da Saúde. Sistema Nacional de Informações Tóxico- Farmacológicas (SINITOX), Dados de intoxicação, Tabela 7. Brasil, 2015

2. Silva, GRF; Cardoso, MVL. Percepção de mães sobre um manual educativo sobre estimulação visual da criança. Rev. Eletr. Enf. 2009;11(4):847-57

3. Deyoung, S. Teaching strategies for nurse educators. New Jersey: Pretince Hall, 2009. 